Jap. J. Physiol., 26, 651-669, 1976

\title{
ANALYSIS OF THE SLOW EXCITATORY POSTSYNAPTIC POTENTIAL IN BULLFROG SYMPATHETIC GANGLION CELLS
}

\author{
Kenji KubA and Kyozo KoKeTsu \\ Department of Physiology, Kurume University School of Medicine, \\ Kurume 830, Japan
}

\begin{abstract}
The ionic mechanism of the slow excitatory postsynaptic potential (slow EPSP), i.e. the muscarinic action of acetylcholine (ACh), was studied either by stimulating preganglionic nerves or by applying $\mathrm{ACh}$ in curarized sympathetic ganglion cells of bullfrogs. There are three different types of cells characterized by the effects of membrane hyperpolarization on the amplitude of slow EPSP. One group of cells showed an increase in amplitude (type 1 cell) and, in two other groups of cells, it remained unchanged (type 2 cell) or decreased (type 3 cell), when the membrane was hyperpolarized. Under the muscarinic effects of ACh, the slope membrane conductance was increased (type 1 cell), unchanged (type 2 cell) or decreased (type 3 cell) at 10-20 mV hyperpolarized levels, while it was unchanged (type 1 cell) or decreased (types 2 and 3 cells) at resting and depolarized levels. In all cells, the slow ACh potential, corresponding to the slow EPSP, was almost completely suppressed in a high $\mathrm{K}^{+}, \mathrm{Ca}^{2+}$-free, $\mathrm{Na}^{+}$-free solution. These results suggest that the slow EPSP is generated by increases in $\mathrm{Na}^{+}$and $\mathrm{Ca}^{2+}$ conductance and also by a simultaneous decrease in the $\mathrm{K}^{+}$conductance.
\end{abstract}

At least, two different types of excitatory postsynaptic potentials can be generated by acetylcholine $(\mathrm{ACh})$ released from preganglionic nerve terminals in sympathetic ganglion cells of vertebrates. They are the fast excitatory postsynaptic potential (fast EPSP: NISHI and KoKETSU, 1960) generated by the nicotinic action of $\mathrm{ACh}$ and the slow excitatory postsynaptic potential (slow EPSP: TosAKA et al., 1968) by the muscarinic action of ACh (see KoKETSU, 1969).

The ionic mechanism of the fast EPSP was found to be similar to that of the end-plate potential, namely it showed increases in the membrane conductance for $\mathrm{Na}^{+}$and $\mathrm{K}^{+}$(see KoKETSU, 1969). The ionic mechanism of the slow EPSP, however, has not been fully elucidated, although some unusual characteristics of

Received for publication July 19, 1976

久場健司, 䋶䋶教三 
this slow synaptic potential have been reported (KoBAYASHI and LIBET, 1968; NisHi et al., 1965, 1969) and WeIGHT and VotaVA (1970) have proposed that the slow EPSP may be produced by a decrease of the $\mathrm{K}^{+}$conductance of cell membrane.

In the present experiment, the ionic mechanisms of the slow EPSP in the bullfrog sympathetic ganglion cells were investigated. Evidence is shown, indicating that the slow EPSP is generated not only by increases in the $\mathrm{Na}^{+}$and $\mathrm{Ca}^{2+}$ conductance, but also by a simultaneous decrease in the $\mathrm{K}^{+}$conductance of cell membrane. A part of the results has appeared in a preliminary report (KUBA and KoKETSU, 1974).

\section{METHODS}

Ninth or tenth lumbar sympathetic ganglia of bullfrogs (Rana catesbeiana) were isolated and continuously perfused during the experiment. Techniques for intracellular recording of the membrane potential of ganglion cells were essentially similar to those described previously (NISHI and KoKETSU, 1960). B type neurones (NisHI et al., 1965), which were identified on the basis of antidromic conduction delay, were subjected to the present experiment.

Glass electrodes were filled with $3 \mathrm{M} \mathrm{KCl}$ and those having tip resistance of 20-50 M $\Omega$ with small junction potential were selected for recording and for injection of current into cells. In most of experiments, a Wheatstone-bridge circuit was used to pass current through a recording electrode. A resistor of 1,000 $\mathrm{M} \Omega$ was put in series with a recording electrode to the one arm of the bridge circuit. When current intensities did not exceed $2 \mathrm{nA}$, changes in the resistance and tip potential of selected microelectrodes were negligible. In some experiments, a second electrode similar to a recording electrode was inserted to the same cell for current injections. Results obtained from the experiments using two electrodes were essentially similar to those using the bridge circuit.

All the experiments were carried out at room temperature $\left(20-24^{\circ} \mathrm{C}\right)$ in the presence of $d$-tubocurarine $(0.14 \mathrm{mM})$, which completely blocked the fast EPSP. Slow ACh potentials, which correspond to the slow EPSP (NISH et al., 1969), were evoked by iontophoretic application of ACh (2 M: KOKETSU et al., 1968). The resistances of $\mathrm{ACh}$ electrodes were 30-100 MS. Current pulses (10-8 $10^{-7} \mathrm{~A}$ for $0.5-5 \mathrm{sec}$ ) for iontophoresis of $\mathrm{ACh}$ were delivered through a $200 \mathrm{M} \Omega$ resistor.

The compositions of normal Ringer's solution and test solutions are listed in Table 1. All the effects of changes in ionic compositions of solutions were observed at least $5 \mathrm{~min}$ after alteration of perfusing solutions. This period was long enough for a change in the compositions of perfusing solutions as seen from the rise time of slow ACh depolarizations (see Figs. 10 and 11), which were induced by perfusion of the ganglion with solutions containing ACh (0.27 mM). Acetylcholine chloride and $d$-tubocurarine chloride were obtained from Wako 
Pure Chemical Ind., Japan. Tetrodotoxin (TTX) and tris-hydroxymethylaminomethan (Tris) were obtained from Sankyo Pharmaceutical Co. and TokyoKasei Ind., Japan, respectively.

Table 1. Ionic compositions of perfusing solutions.

\begin{tabular}{|c|c|c|c|c|c|c|c|c|}
\hline & $\mathrm{NaCl}$ & $\begin{array}{c}\mathrm{Na-} \\
\text { glutamate }\end{array}$ & $\mathrm{KCl}$ & $\mathrm{NaHCO}_{3}$ & $\mathrm{CaCl}_{2}$ & $\mathrm{MgCl}_{2}$ & Sucrose & Tris \\
\hline Normal Ringer & 112.0 & - & 2.0 & 2.0 & 1.8 & - & - & - \\
\hline High $\mathrm{K}^{+}$ & 104.0 & - & 10.0 & 2.0 & 1.8 & - & - & - \\
\hline High $\mathrm{K}^{+}, \mathrm{Ca}^{2+}$-free & 106.7 & - & 10.0 & 2.0 & - & - & - & - \\
\hline High $\mathrm{K}^{+}, \mathrm{Na}^{+}$-free (sucrose) & - & - & 10.0 & - & 1.8 & - & 212.0 & - \\
\hline High $\mathrm{K}^{+}, \mathrm{Na}^{+}$-free (Tris) & - & - & 10.0 & - & 1.8 & 一 & - & 106.0 \\
\hline $\begin{array}{l}\text { High } \mathrm{K}^{+}, \mathrm{Ca}^{2+} \text {-free, } \\
\mathrm{Na}^{+} \text {-free (sucrose) }\end{array}$ & - & - & 10.0 & - & - & - & 217.4 & - \\
\hline $\begin{array}{l}\text { High } \mathrm{K}^{+}, \mathrm{Ca}^{2+} \text {-free, } \\
\mathrm{Na}^{+} \text {-free (Tris) }\end{array}$ & - & - & 10.0 & - & - & - & - & 108.7 \\
\hline High $\mathrm{K}^{+}, \mathrm{Cl}^{-}$-deficient & - & 104.0 & 10.0 & 2.0 & 1.8 & 一 & - & - \\
\hline High $\mathrm{K}^{+}$, isotonic- $\mathrm{Ca}^{2+}$ & - & - & 10.0 & - & 70.0 & 一 & 一 & - \\
\hline High $\mathrm{K}^{+}$, isotonic- $\mathrm{Mg}^{2+}$ & - & - & 10.0 & - & 一 & 70.0 & - & - \\
\hline
\end{tabular}

Concentrations are expressed in mM. $\mathrm{pH}$ of the solutions containing tris-hydroxymethylaminomethan (Tris) were adjusted by $0.2 \mathrm{~N} \mathrm{HCl}$ to 7.0 .

\section{RESULTS}

Relationship between the amplitude of the slow EPSP and membrane potential

Ganglion cells (B type) could be classified into three types according to the effects of membrane hyperpolarization on the amplitude of the slow EPSP (NISHI et al., 1969). The first type of cells (type 1) exhibited an increase in the slow EPSP amplitude when the cell membrane was hyperpolarized to a level more than that of the equilibrium potential for $\mathrm{K}^{+}\left(E_{\mathrm{K}}\right)$, which was identified from the reversal level of the after-hyperpolarization of an action potential (BLACKMAN et al., 1963). An example of these cells is shown in Fig. 1, where the slow EPSP and antidromic action potentials were recorded at various hyperpolarized levels of membrane potential. In the second type of cells (type 2), the slow EPSP amplitude remained unchanged with membrane hyperpolarization to a level exceeding $E_{\mathrm{K}}$ as can be seen in Fig. 2. In majority of cells of both types, the amplitude of the slow EPSP was slightly decreased with small hyperpolarization (less than $10 \mathrm{mV}$ ). However, further and greater hyperpolarization of the membrane to levels more than $E_{\mathrm{K}}$ did not cause any signs of a reduction of the slow EPSP amplitude in all cells of these two types (see also KoBAYASHI and LIBET, 1974). These results are inconsistent with the results of WeIGHT and Votava (1970).

In cells of the third type (type 3), shown in Fig. 3, membrane hyperpolarization resulted in decreases in the slow EPSP amplitude and abolished it at a level close to $E_{\mathrm{K}}$. We persisted in trying to find a reversal of the slow EPSP at a level 


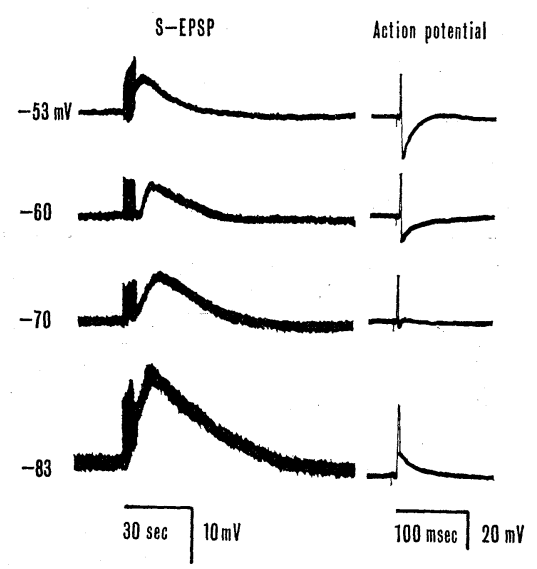

Fig. 1. Effects of membrane hyperpolarization on the slow EPSP and action potentials recorded from the type 1 cell. The resting membrane potential was $-53 \mathrm{mV}$. Action potentials were evoked by antidromic stimulations. A part of the spike of action potentials is not shown.

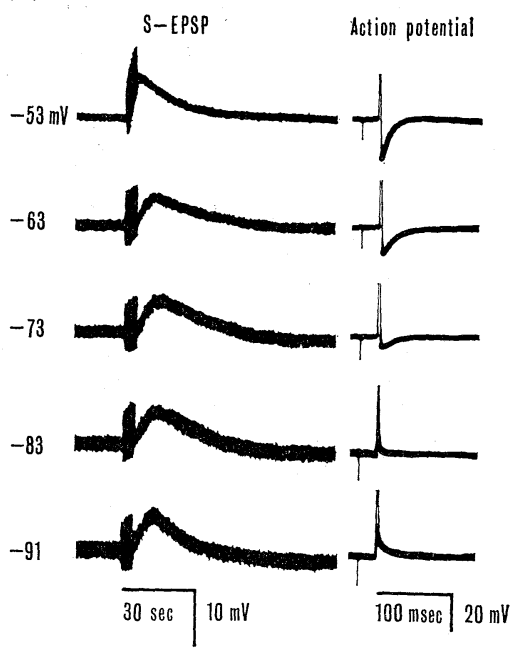

Fig. 2. Effects of membrane hyperpolarization on the slow EPSP and action potentials recorded from the type 2 cell. The resting membrane potential was $-53 \mathrm{mV}$. Other explanations are the same as those of Fig. 1.

more than $E_{\mathrm{K}}$, however, we did not succeed in demonstrating the reversal of the slow EPSP in cells of type 3; the slow EPSP merely decreased in amplitude and disappeared at levels more than $E_{\mathrm{K}}$. WeIGHT and VotAVA (1970), however, observed a reversal of the slow EPSP at a level more than $E_{\mathrm{K}}$. The reversed slow EPSP seen by them could be partly contaminated by the slow inhibitory post- 


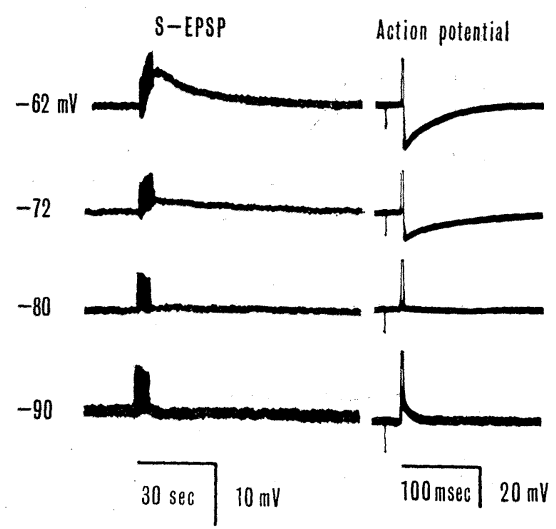

Fig. 3. Effects of membrane hyperpolarization on the slow EPSP and action potentials recorded from the type 3 cell. The resting membrane potential was $-62 \mathrm{mV}$. Other explanations are the same as those of Fig. 1.

synaptic potential (slow IPSP), or merely its manifestation, since the slow IPSP became prominent when the fast EPSP was blocked by nicotine (KOBAYASHI and LIBET, 1974) and when the membrane was hyperpolarized (NISHI and KoKETSU, 1968). Thirteen cells out of thirty cells studied were found to be type 1 , ten were type 2 and seven were type 3 .

In Fig. 4, the amplitudes of the slow EPSP shown in Figs. 1, 2, and 3, were plotted against membrane potential. Changes in the slow EPSP at depolarized levels were not studied because stable and large membrane depolarization could not be maintained long enough to record the slow EPSP because of a drop in membrane resistance due to the delayed rectification (see Figs. 5, 6, and 7). According to voltage-current relationships, which will be described in the next section, the slow EPSP amplitude seems to increase or to remain unchanged at depolarized levels even in types 1 and 2 cells. Thus, there seems to be no reversal potential for the slow EPSP in these types of cells.

\section{Conductance changes during transmitter actions}

In order to observe changes in the membrane conductance during muscarinic actions of ACh by which the slow EPSP is generated, voltage-current relationships (V-I curve) of the ganglion cell membrane were obtained in the presence of $d$ tubocurarine $(0.14 \mathrm{mM}$ ) and tetrodotoxin (TTX; $1.6 \mu \mathrm{M})$, with and without ACh $(0.27 \mathrm{~mm})$. Results of these experiments obtained with types 1,2 , and 3 cells are shown in Figs. 5, 6, and 7, respectively. The use of TTX was substantiated by the fact that the toxin did not affect the amplitude of the slow ACh potential in a high $\mathrm{K}^{+}$solution (the amplitude of the slow ACh potentials in a high $\mathrm{K}^{+}$solution with $\operatorname{TTX}(1.6 \mu \mathrm{M})$ was $97.5 \pm 2.3 \%(n=4)$ of that in a high $\mathrm{K}^{+}$solution without TTX). 


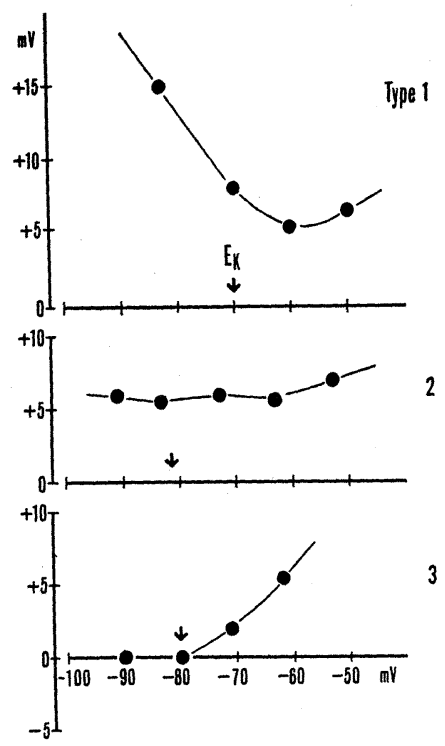

Fig. 4. The amplitudes of the slow EPSP recorded from the types 1, 2, and 3 cells shown in Figs. 1, 2, and 3, respectively, were plotted against membrane potentials. $E_{\mathrm{K}}$ was determined from the reversal level of the after-hyperpolarization of action potentials.

In type 1 cells (Fig. 5), the slope of the V-I curve in the presence of ACh was greater than that of the control at levels more negative than a $10 \mathrm{mV}$ hyperpolarized level, indicating an increase in the membrane conductance. In the absence of $\mathrm{ACh}$, the delayed rectification occurred at the resting potential level or at a slightly hyperpolarized level, and was fully activated at depolarized levels. On the other hand, in the presence of $\mathrm{ACh}$, the slope of the curve remained unchanged up to a $20 \mathrm{mV}$ depolarized level, at which the membrane started to rectify. Thus, under the muscarinic effects of $\mathrm{ACh}$, the membrane conductance was decreased in a potential range between a $10 \mathrm{mV}$ hyperpolarized level and about a $20 \mathrm{mV}$ depolarized level. Differences between the two curves along the voltage axis, which are equivalent to the amplitude of the slow $\mathrm{ACh}$ depolarization, were plotted against membrane potential levels of the normal condition in the upper diagram of Fig. 5. This curve well represents the relationship between the amplitude of the slow EPSP and membrane potential shown in Fig. 4.

In type 2 cells (Fig. 6), the membrane conductance during muscarinic action of $\mathrm{ACh}$, remained unchanged at levels more negative than a $5 \mathrm{mV}$ hyperpolarized level from the original resting potential, while increased at levels more positive than this potential. A relationship between the slow ACh depolarization and membrane potential shown in the upper diagram of Fig. 6 well agrees with the slow EPSP-membrane potential relationship shown in the middle graph of Fig. 4 .

In type 3 cells (Fig. 7), the membrane conductance during muscarinic action 


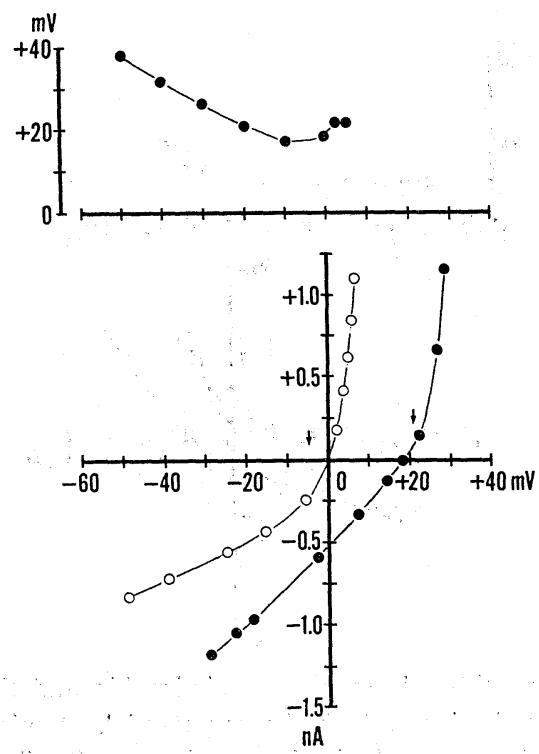

Fig. 5. Upper graph: A relationship between the amplitudes of slow ACh depolarization and membrane potential. Differences between the two curves along the abscissa shown in the lower graph were plotted against membrane potential without ACh. Scales of abscissa correspond to those in the lower graph. Lower graph: Effects of ACh on the voltage-current relationship obtained from the type 1 cell in the presence of $d$-tubocurarine $(0.14 \mathrm{mM})$ and TTX $(1.6 \mu \mathrm{M})$. Positive and negative signs of the abscissa indicate membrane depolarization and hyperpolarization, respectively, from the original resting potential without $\mathrm{ACh}$, which was $-50 \mathrm{mV}$. Levels of membrane potential were measured at the end of electrotonic potentials of $300 \mathrm{msec}$ duration. Positive and negative signs of the current axis indicated depolarizing and hyperpolarizing currents, respectively. Open circles are the relationship without $\mathrm{ACh}$, while filled circles with $\mathrm{ACh}$. Arrows indicate the threshold membrane potential for delayed rectification.

of ACh was decreased in the entire range of membrane potential measured. Furthermore, the two curves crossed each other at a $30 \mathrm{mV}$ hyperpolarized level. The amplitude of the muscarinic ACh depolarization decreased with membrane hyperpolarization and was nullified at a $30 \mathrm{mV}$ hyperpolarized level. This is generally similar to the relationship of the slow EPSP to membrane potential shown in the lower graph of Fig. 4, except at hyperpolarized levels of more than $30 \mathrm{mV}$. Hyperpolarizing responses to muscarinic $\mathrm{ACh}$ action are expected at levels over $30 \mathrm{mV}$. negative to resting potentials (Fig. 7).

Large variations in the muscarinic effects of ACh on the membrane conductance at different levels of membrane potential, which were obtained with 50 different cells, are shown in Fig. 8. Changes in the membrane conductance under the effects of $\mathrm{ACh}$ at levels more negative than $20 \mathrm{mV}$ hyperpolarized potentials varied from a marked increase by $250 \%$ of the control to a decrease by $50 \%$ of 


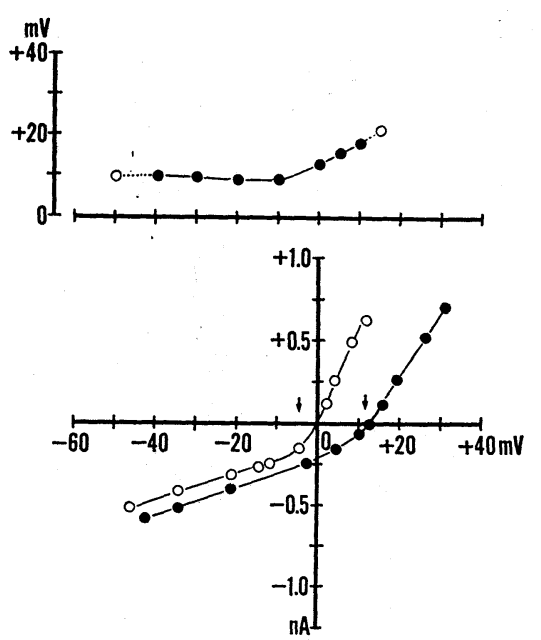

Fig. 6. Effects of ACh on the voltage-current relationship and the relationship between muscarinic ACh depolarization and membrane potential. Explanations are the same as those of Fig. 5, but data were obtained from the type 2 cell. Resting potential was $-52 \mathrm{mV}$. Open circles in the upper graph were obtained by extrapolation of the curves in the lower graph.

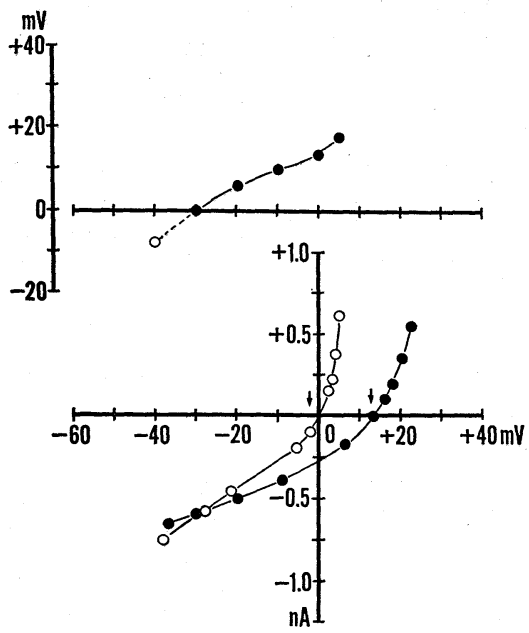

Fig. 7. Effects of $\mathrm{ACh}$ on the voltage-current relationship and the relationship between muscarinic ACh depolarization and membrane potential. Explanations are the same as those of Fig. 5, but data were obtained from the type 3 cell. Resting potential was $-56 \mathrm{mV}$. Open circles in the upper graph were obtained by extrapolation of the curves in the lower graph. 
the control. However, in all the types of cells ( 3 exceptions in 50 cells), when the membrane potential was fixed at the original resting potential level or at depolarized potentials, the slope conductance of the membrane decreased or was at least unchanged during the muscarinic actions of ACh (cf. NisHI et al., 1969; KobAyASHI and LibET, 1970; KuBA and KoKetsu, 1975).

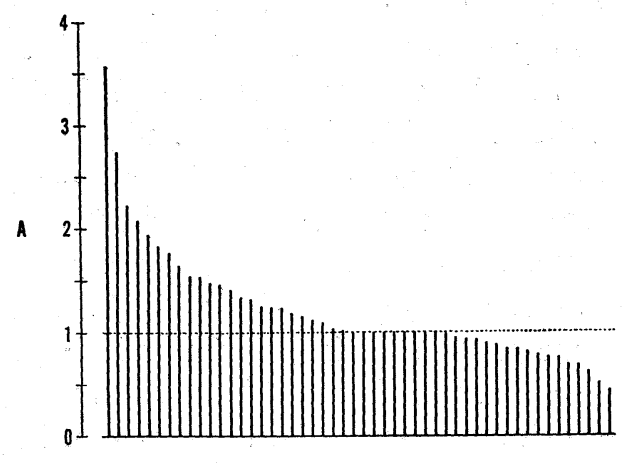

B
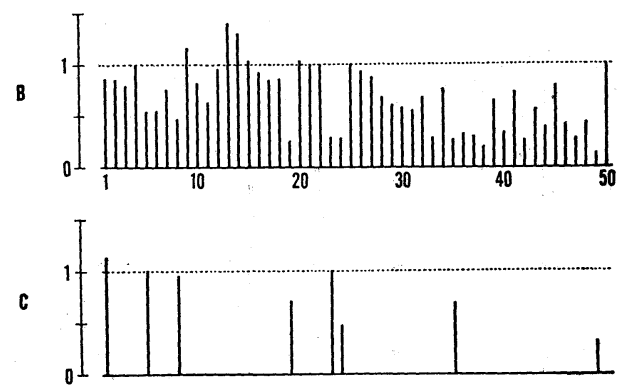

Fig. 8. Changes in the slope conductance of the ganglionic cell membrane at different levels of membrane potential. Data were obtained from fifty different cells and arranged in abscissae in the order of magnitude of the conductance changes at hyperpolarized levels. Values are expressed by the ratio of the slope conductance in the presence of ACh $(0.27 \mathrm{~mm})$ to that in the absence of ACh. Ordinates are the ratios of the conductance. Dotted lines indicate the control value. Abscissae represent the number of cells. Each columns in B correspond to those in A and C. Values in A are the ratios of the slope conductances measured at a $10-20 \mathrm{mV}$ hyperpolarized level. Those in B are the ratios at the original resting potential. Those in $\mathrm{B}$ are the ratios at the original resting potential. Those in $\mathrm{C}$ are the ratios at depolarized levels at which delayed rectification was fully activated. Cells, in which the conductance at a depolarized level was measured, were perfused with the solution containing TTX $(1.6 \mu \mathrm{M})$.

It should be pointed out that in all the types of cells, there was a shift of the threshold membrane potential for delayed rectification to a more positive value by $10-15 \mathrm{mV}(12.3 \pm 0.7 \mathrm{mV}$ (s.e.), $n=19)$, when the ganglion cell was perfused with the solution containing ACh. 


\section{Role of $K^{+}$in the mechanism of the muscarinic ACh depolarization}

Decreases of the ion conductance during the membrane depolarization of ganglion cells in response to the muscarinic action of $\mathrm{ACh}$ in the types 2 and 3 cells (Figs. 6, 7, and 8) highly suggest the inactivation of membrane conductance for $\mathrm{K}^{+}\left(G_{\mathrm{K}}\right)$. Therefore, effects of high concentration of $\mathrm{K}^{+}$were examined on both the slow ACh potentials evoked by iontophoretic application and the slow $\mathrm{ACh}$ depolarization induced by perfusion of $\mathrm{ACh}(0.27 \mathrm{~mm})$. In a high $\mathrm{K}^{+}$ $(10 \mathrm{mM})$ solution, the resting membrane potential decreased slightly from $-52.9 \pm$ $0.8 \mathrm{mV}(n=54)$ in the normal Ringer's solution to $-47.6 \pm 0.9 \mathrm{mV}(n=31)$, while the $E_{\mathrm{K}}$, estimated from the reversal level of the after-hyperpolarization of action potentials, was markedly reduced from $-84.0 \pm 2.5 \mathrm{mV}(n=11)$ to $-57.2 \pm 1.6 \mathrm{mV}$ $(n=9)$. Thus, the $E_{\mathrm{K}}$ became close to the resting potential under this condition. If the slow $\mathrm{ACh}$ responses are generated by the inactivation of the $G_{\mathrm{K}}$, the decrease in the difference between the resting potential and $E_{\mathrm{K}}$ should result in a reduction of their amplitude. Some of the experiments shown in Figs. 9 and 10 indicates that this was the case. An increase in the $\mathrm{K}^{+}$concentration $(10 \mathrm{~mm})$ of the perfusing solution resulted in suppression of both the slow ACh potentials (Fig. 9a,

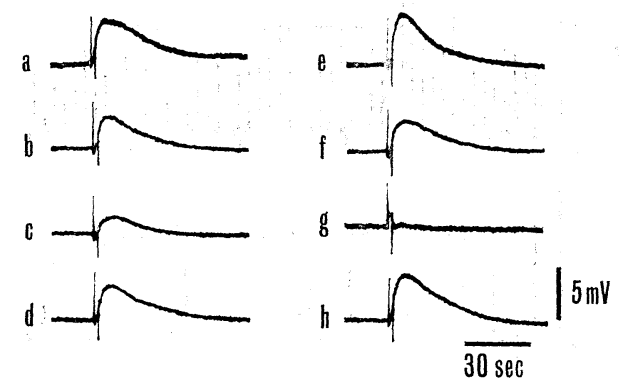

Fig. 9. Effects of high $\mathrm{K}^{+}, \mathrm{Ca}^{2+}$-free and $\mathrm{Na}^{+}$-free (sucrose) solutions on the slow $\mathrm{ACh}$ potentials in the presence of $d$-tubocurarine $(0.14 \mathrm{~mm})$. a: normal Ringer's solution, $\mathrm{b}$ : high $\mathrm{K}^{+}(10 \mathrm{~mm})$ solution, $\mathrm{c}$ : high $\mathrm{K}^{+}, \mathrm{Ca}^{2+}$-free solution, $\mathrm{d}$ : same as $\mathrm{b}$, e: same as $\mathrm{a}, \mathrm{f}$ : same as $\mathrm{b}$, $\mathrm{g}$ : high $\mathrm{K}^{+}, \mathrm{Ca}^{2+}$-free and $\mathrm{Na}^{+}$-free (replaced with sucrose) solution, $\mathrm{h}$ : same as a. Current pulses were $1 \times 10^{-7} \mathrm{~A}$ and $2 \mathrm{sec}$. Each record was obtained from the same single cell in series. The recordings were made at least $5 \mathrm{~min}$ after changing the perfusing solutions.

b, d, e, f) and the slow ACh depolarizations (Fig. 10Aa and b; see also Figs. 10B and 11A). The amplitudes of slow ACh potentials and slow ACh depolarizations decreased to $72 \%$ (see Table 3 ) and $79 \%$ (see Table 2 ) of the controls, respectively, in a high $\mathrm{K}^{+}$solution. One might argue that depolarization of the ganglion cell membrane would have caused a decrease in the amplitudes of the slow ACh potentials and slow ACh depolarizations. However, this did not occur as shown by the relationships between the slow ACh responses and membrane potential in Figs. 5, 6, and 7 . 


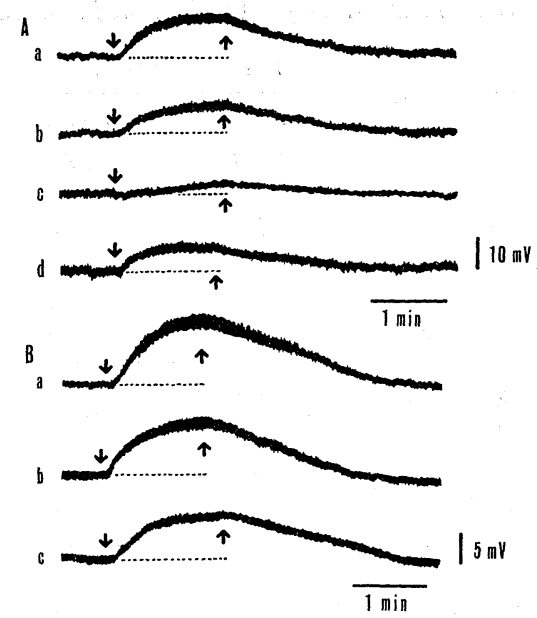

Fig. 10. A) Effects of replacement of $\mathrm{NaCl}$ with sucrose on the slow ACh depolarization in a high $\mathrm{K}^{+}$solution. Upward and downward arrows indicate the beginning and end of application of ACh $(0.27 \mathrm{~mm})$, respectively. a: normal Ringer's solution, b: high $\mathrm{K}^{+}$ $(10 \mathrm{~mm})$ solution, $\mathrm{c}$ : high $\mathrm{K}^{+}, \mathrm{Na}^{+}$-free (sucrose) solution, $\mathrm{d}$ : high $\mathrm{K}^{+}$solution. B) Effects of replacement of $\mathrm{NaCl}$ with Tris- $\mathrm{Cl}$ on the slow ACh depolarization in a high $\mathrm{K}^{+}$solution. Upward and downward arrows indicate the beginning and end of treatment of the preparation with ACh $(0.27 \mathrm{~mm})$. a: normal Ringer's solution, $b$ : high $\mathrm{K}^{+}$ (10 mM) solution, c: high $\mathrm{K}^{+}, \mathrm{Na}^{+}$-free (Tris) solution.

Table 2. Slow ACh depolarization in different ionic media.

\begin{tabular}{|c|c|c|c|c|}
\hline & \multicolumn{2}{|c|}{ Amplitude (mV) } & \multicolumn{2}{|c|}{ Ratio $(\%)$} \\
\hline Normal Ringer & $10.4 \pm 0.9$ & (s.e.) $n=20$ & - & \\
\hline High $\mathrm{K}^{+}$ & $7.2 \pm 0.7$ & 16 & $78.6 \pm 4.3$ & \\
\hline High $\mathrm{K}^{+}, \mathrm{Na}^{+}$-free (sucrose) & $2.5 \pm 0.8$ & 6 & $28.7 \pm 7.4$ & 6 \\
\hline High $\mathrm{K}^{+}, \mathrm{Na}^{+}$-free (Tris) & $6.9 \pm 0.5$ & 4 & $79.9 \pm 11.2$ & 4 \\
\hline High $\mathrm{K}^{+}, \mathrm{Cl}^{-}$-deficient & $5.6 \pm 1.0$ & 6 & $72.2 \pm 8.6$ & 6 \\
\hline High $\mathrm{K}^{+}$, isotonic- $\mathrm{Ca}^{2+}$ & $11.5 \pm 1.5$ & 3 & $95.0 \pm 11.3$ & 3 \\
\hline High $\mathrm{K}^{+}$, isotonic- $\mathrm{Mg}^{2+}$ & $10.2 \pm 0.7$ & 5 & $87.5 \pm 8.6$ & 5 \\
\hline
\end{tabular}

Effects of ionic changes in the perfusing solution were observed on the same individual cells. Values in the right column are the ratios of the amplitude of the slow ACh depolarizations in different ionic solutions to those in the normal Ringer's solution in individual cells. ACh concentration was $0.27 \mathrm{~mm}$.

\section{Role of $\mathrm{Na}^{+}$}

In order to clarify which ions are responsible for an increase in the membrane conductance during muscarinic action of $\mathrm{ACh}$, effects of removal of $\mathrm{Na}^{+}$on both the slow ACh potentials and slow ACh depolarizations were examined in a high $\mathrm{K}^{+}$solution (Figs. 9 and 10). Under this condition, the contribution of the $G_{\mathrm{K}}$ inactivation to the depolarizing actions of $\mathrm{ACh}$ is so small that effects of removal 
Table 3. Slow ACh potentials in different ionic solutions.

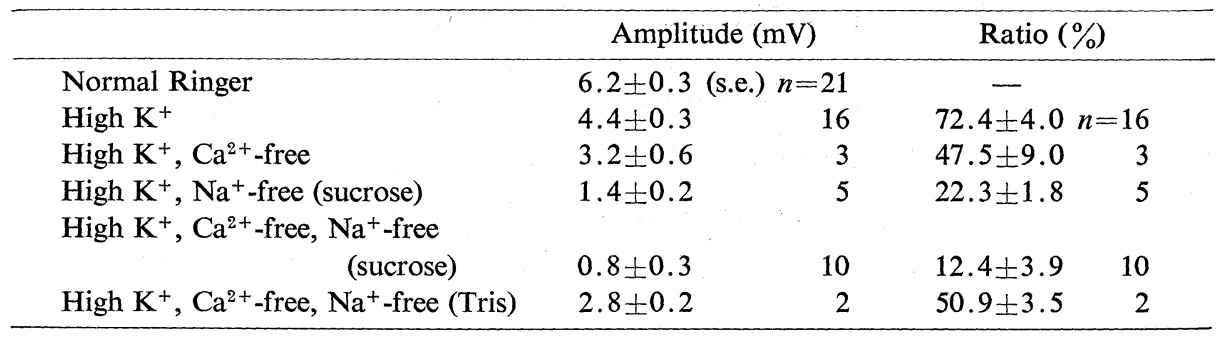

Effects of ionic changes in the perfusing solution were observed on the same individual cells. Values in the right column are the ratios of the amplitude of the slow ACh potentials in different ionic solutions to those in the normal Ringer's solution in individual cells. The slow ACh potentials were evoked by iontophoretic application ACh (2 M). Current pulses for iontophoresis were 10-100 nA for $0.5-5 \mathrm{sec}$.

of $\mathrm{Na}^{+}$would easily be manifested, if they existed. Sucrose and Tris were employed as substitutes for $\mathrm{Na}^{+}$.

When $\mathrm{Na}^{+}$in the high $\mathrm{K}^{+}$solution was totally replaced with either sucrose or Tris, resting membrane potentials showed no significant changes; those in the sucrose and Tris solutions were $-47.6 \pm 2.1 \mathrm{mV}(n=7)$ and $-46.8 \pm 4.2 \mathrm{mV}$ $(n=4)$, respectively. Figure 10 shows the effects of $\mathrm{Na}^{+}$removal on the slow ACh depolarizations induced by perfusion of ACh $(0.27 \mathrm{~mm})$. Replacement of $\mathrm{Na}^{+}$with sucrose in the high $\mathrm{K}^{+}$solution resulted in a marked decrease in the amplitude of the slow ACh depolarization to $29 \%$ of the control (Fig. 10A; see Table 2), while substitution of $\mathrm{Na}^{+}$with Tris did not cause any change in the response (Fig. 10B; see Table 2). Slow ACh potentials were similarly affected by the removal of $\mathrm{Na}^{+}$. The amplitude of the slow ACh potentials markedly decreased to $22 \%$ of the control in a high $\mathrm{K}^{+}$solution in which $\mathrm{NaCl}$ was replaced with sucrose (Table 3; see also Fig. 2 of KUBA and KoKeTsu, 1974). Similar suppressing effects of replacement of $\mathrm{Na}^{+}$with sucrose on the slow ACh potential were also observed in a high $\mathrm{K}^{+}, \mathrm{Ca}^{2+}$-free solution as shown in Fig. 9 (f, $g, h$ ) and in Table $3(12.4 \%$ of the control in this solution). On the other hand, replacement of $\mathrm{Na}^{+}$with Tris in the high $\mathrm{K}^{+}, \mathrm{Ca}^{2+}$-free solution had no significant effects on the slow ACh potentials (see Table 3).

Input resistance of the ganglion cell in the high $\mathrm{K}^{+}, \mathrm{Na}^{+}$-free (sucrose) solution was $124 \pm 27 \%(n=6)$ of that in the high $\mathrm{K}^{+}$solution, indicating that the suppressions of the slow $\mathrm{ACh}$ depolarization and the slow $\mathrm{ACh}$ potentials were not due to a change in the input resistance in this solution. Thus, it may be concluded that there is an increase in the membrane conductance for $\mathrm{Na}^{+}\left(G_{\mathrm{Na}}\right)$ during generation of the slow ACh depolarization or slow ACh potentials. Implications on the lack of effects of $\mathrm{Na}^{+}$substitution with Tris will be discussed later.

Lack of effects of anion $\left(\mathrm{Cl}^{-}\right)$

There is some evidence indicating that the membrane conductance for $\mathrm{Cl}^{-}$ 
$\left(G_{\mathrm{C} 1}\right)$ dose not participate in the slow muscarinic ACh response (NISHI et al., 1969; WeIGHT and Votava, 1970). However, the role of the $G_{\mathrm{K}}$ was not eliminated, when effects of $\mathrm{Cl}^{-}$removal on the slow EPSP were tested in the previous investigation (WeIGHT and Votava, 1970). Therefore, we examined the possibility of this in the high $\mathrm{K}^{+}$solution.

As shown in Fig. 11A, there was no significant change in the amplitude of the slow $\mathrm{ACh}$ depolarization, when total $\mathrm{NaCl}$ was replaced with Na-glutamate

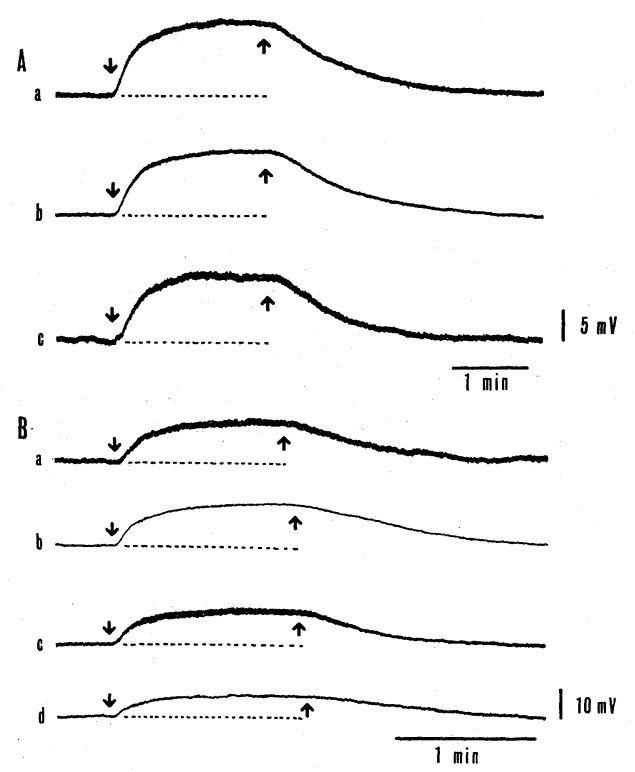

Fig. 11. A) Lack of effects of $\mathrm{Cl}^{-}$deficience on the slow ACh depolarization in a high $\mathrm{K}^{+}$ solution. Upward and downward arrows indicate the beginning and end of application of ACh $(0.27 \mathrm{~mm})$, respectively. a: normal Ringer's solution, b: high $\mathrm{K}^{+}$solution, c: high $\mathrm{K}^{+}, \mathrm{Cl}^{-}$-deficient solution (glutamate ions; $104 \mathrm{mM}, \mathrm{Cl}^{-} ; 13.6 \mathrm{~mm}$ ). B) Slow $\mathrm{ACh}$ depolarizations in high $\mathrm{K}^{+}$, isotonic- $\mathrm{Ca}^{2+}$ and high $\mathrm{K}^{+}$, isotonic- $\mathrm{Mg}^{2+}$ solutions. Upward and downward arrows represent the beginning and end of treatment of the ganglion with ACh $(0.27 \mathrm{mM})$, respectively. a: normal Ringer's solution, b: high $\mathrm{K}^{+}(10 \mathrm{~mm})$, isotonic- $\mathrm{Ca}^{2+}$ solution $\left(\mathrm{CaCl}_{2} ; 70 \mathrm{mM}\right), \mathrm{c}$ : normal Ringer's solution, $\mathrm{d}$ : high $\mathrm{K}^{+}$, isotonic$\mathrm{Mg}^{2+}$ solution.

in the high $\mathrm{K}^{+}$solution (see also Table 2). Resting potential and input resistance of the cell membrane in the high $\mathrm{K}^{+}, \mathrm{Cl}^{-}$-deficient solution were $-46.7 \pm 2.2 \mathrm{mV}$ $(n=6)$ and $124 \pm 13 \%$ of the value in the high $\mathrm{K}^{+}$solution, respectively. Therefore, it is quite clear that $\mathrm{Cl}^{-}$does not play a role in the generation of the slow ACh depolarization. This can also be supported by the effects of replacement of total $\mathrm{NaCl}$ with sucrose (see preceding section) on the slow ACh potentials and the slow ACh depolarization. 


\section{Role of $\mathrm{Ca}^{2+}$}

It is possible that an increase in the $\mathrm{Ca}^{2+}$ conductance $\left(G_{\mathrm{Ca}}\right)$ of the ganglionic membrane may be responsible for the generation of slow ACh potentials and depolarizations, since these potential changes could still be recorded in a high $\mathrm{K}^{+}, \mathrm{Na}^{+}$-free (sucrose) solution containing $2 \mathrm{mM} \mathrm{Ca}^{2+}$. As shown in Fig. 9 (b, $\mathrm{c}, \mathrm{d})$, the slow $\mathrm{ACh}$ potential decreased, when total $\mathrm{Ca}^{2+}$ was removed from the high $\mathrm{K}^{+}$solution. This finding was comparable with the observation that the slow $\mathrm{ACh}$ potentials were almost eliminated in a high $\mathrm{K}^{+}, \mathrm{Ca}^{2+}$-free, $\mathrm{Na}^{+}$-free (sucrose) solution (Fig. 9g). When $\mathrm{Ca}^{2+}$ was removed from the high $\mathrm{K}^{+}$solution, the input resistance of the cell membrane was almost unchanged $(113 \pm 14 \%$ $(n=14)$ of the control). Furthermore, the resting membrane potentials in the high $\mathrm{K}^{+}, \mathrm{Ca}^{2+}$-free solution and in the high $\mathrm{K}^{+}, \mathrm{Ca}^{2+}$-free, $\mathrm{Na}^{+}$-free (sucrose) solution were $-45.6 \pm 1.9 \mathrm{mV}(n=7)$ and $-44.8 \pm 2.4 \mathrm{mV}(n=9)$, respectively, which were not significantly different from $-47.6 \pm 0.9 \mathrm{mV}(n=31)$ in the high $\mathrm{K}^{+}$solution. The mean amplitude of the slow ACh potential in the high $\mathrm{K}^{+}$, $\mathrm{Ca}^{2+}$-free solution was $47 \%$ of the control value, which was significantly smaller than $72 \%$ in the high $\mathrm{K}^{+}$solution (Table 3 ).

Figure 11B shows slow ACh depolarizations in the isotonic $\mathrm{Ca}^{2+}$ or $\mathrm{Mg}^{2+}$ solution containing $10 \mathrm{~mm} \mathrm{~K} \mathrm{~K}^{+}$. The amplitude of the slow ACh depolarization in a high $\mathrm{K}^{+}$, isotonic- $\mathrm{Ca}^{2+}$ solution was almost similar to that in the normal Ringer's solution (see Table 2). The mean amplitude of slow ACh depolarization in the high $\mathrm{K}^{+}$, isotonic- $\mathrm{Mg}^{2+}$ solution, which lacked $\mathrm{Na}^{+}$and $\mathrm{Ca}^{2+}$, was $88 \%$ of the control (see Table 2). This value is much greater than those of slow ACh potentials in any of various $\mathrm{Ca}^{2+}$-free solutions (see Table 3). Thus, these results would indicate that the reduction of the slow ACh potentials in the $\mathrm{Ca}^{2+}$-free solution was not principally due to the decrease in the sensitivity of the postsynaptic membrane to ACh (Del CASTillo and Katz, 1955; Lambert and PARSONS, 1970), but mainly to the absence of $\mathrm{Ca}^{2+}$ in the extracellular space as a charge carrier. The time courses of the recoveries of the membrane potential following the removal of $\mathrm{ACh}$ was slower in the high $\mathrm{K}^{+}$, isotonic- $\mathrm{Ca}^{2+}$ or $\mathrm{Mg}^{2+}$ solution than that in the normal Ringer's solution. Resting membrane potentials in the high $\mathrm{K}^{+}$, isotonic- $\mathrm{Ca}^{2+}$ and $\mathrm{Mg}^{2+}$ solutions were $-48.2 \pm 1.7 \mathrm{mV}(n=3)$ and $-54.8 \pm$ $7.5 \mathrm{mV}(n=4)$, respectively.

These results imply that the membrane conductance for $\mathrm{Ca}^{2+}\left(G_{\mathrm{Ca}}\right)$ increases during the muscarinic effects of ACh in the ganglion cell membrane, and further indicate that the $G_{\mathrm{Ca}}$ channels for this response can also afford to allow $\mathrm{Mg}^{2+}$ to pass.

\section{DISCUSSION}

It was suggested that the slow EPSP might be produced by an inactivation of the $G_{\mathrm{K}}$ of the ganglion cell membrane (WeIGHT and VotAVA, 1970). This suggestion was partly supported by the findings in the present study that the amplitudes 
of the slow ACh potentials and depolarizations were decreased in a high $\mathrm{K}^{+}$ solution (Figs. 9 and 10) and the membrane resistance increased during the slow ACh depolarizations in type 3 cells. However, the present experiments further indicate that the slow EPSP appears to be generated not only by an inactivation of the $G_{\mathrm{K}}$ but also by simultaneous activations of the $G_{\mathrm{Na}}$ and $G_{\mathrm{Ca}}$ of the cell membrane. The possibility that the generation of the slow EPSP is caused by activation of the $G_{\mathrm{Na}}$ and $G_{\mathrm{Ca}}$ is based on the observations that the amplitudes of $\mathrm{ACh}$ potentials and depolarizations were reduced when $\mathrm{Na}^{+}$or $\mathrm{Ca}^{2+}$ was removed in the Ringer's solution containing $10 \mathrm{mM} \mathrm{K}^{+}$and there was a decrease in the membrane resistance during the slow $\mathrm{ACh}$ depolarizations in type 1 cells. Furthermore, the slow $\mathrm{ACh}$ potential was almost eliminated when both $\mathrm{Na}^{+}$and $\mathrm{Ca}^{2+}$ were removed from this solution. Figure 12 schematically illustrates ionic mechanisms of the slow EPSP. If inactivation of the $G_{\mathrm{K}}$ of the cell membrane occurs by the action of transmitters, an inward or outward current $\left(I_{\mathrm{K}}\right.$; interrupted lines)

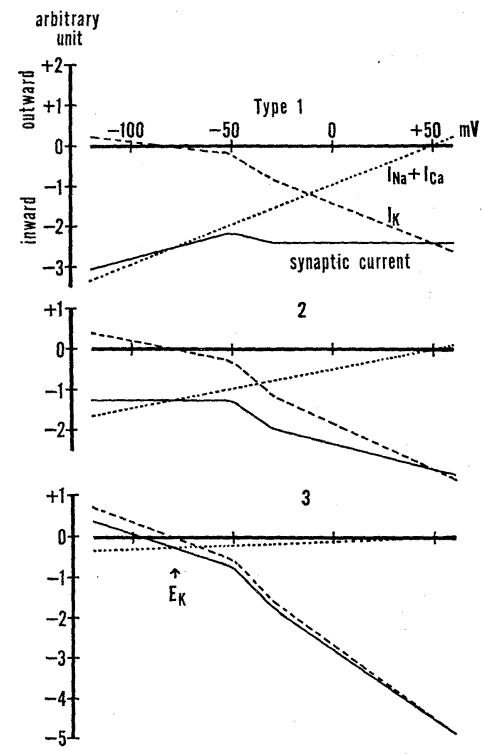

Fig. 12. A hypothetical model of ionic currents for the slow EPSP in the bullfrog sympathetic ganglion cells. Ordinates are membrane currents in arbitrary units. Inward and outward currents were taken as negative and positive, respectively. Abscissae represent membrane potential. Interrupted lines indicate $\mathrm{K}^{+}$currents caused by the inactivation of the $G_{\mathrm{K}}$. The value for the $E_{\mathrm{K}}$ was taken as $-80 \mathrm{mV}$, since the $E_{\mathrm{K}}$ of many cells were close to this value in the present experimental conditions. Dotted lines indicate the sum of the $\mathrm{Na}^{+}$and $\mathrm{Ca}^{2+}$ currents caused by activation of the $G_{\mathrm{Na}}$ and $G_{\mathrm{Ca}}$. The reversal level of this current was assumed to be as $+50 \mathrm{mV}$. Although there is no basis for this assumption except that equilibrium potentials for $\mathrm{Na}^{+}$and $\mathrm{Ca}^{2+}$ would be positive values, this assumption would not affect the significance of this model. Continuous lines are synaptic currents for the slow EPSP. See text. 
would flow through the membrane at potential levels more positive or more negative than the $E_{\mathrm{K}}$, respectively. If activation of the $G_{\mathrm{Na}}$ and $G_{\mathrm{Ca}}$ occurs, inward currents ( $I_{\mathrm{Na}}$ and $I_{\mathrm{Ca}}$; dotted lines) would flow through the membrane at potential levels more negative than $E_{\mathrm{Na}}$ and $E_{\mathrm{Ca}}$, respectively. Thus, the amplitude of the slow EPSP would be determined by the sum of $I_{\mathrm{K}}, I_{\mathrm{Na}}$ and $I_{\mathrm{Ca}}$ (continuous lines).

It is demonstrated in the present study that there are three different types of the slow EPSP characterized by the effects of membrane hyperpolarization on it. The amplitude of the slow EPSP increased (type 1), unchanged (type 2) or decreased (type 3) when the membrane was hyperpolarized more than $10 \mathrm{mV}$ (Figs. $1,2,3$, and 4). The natures of the three different types of cells could be reasonably explained if one assumes that the ratio of the inactivation of the $G_{\mathrm{K}}$ to the activation of $G_{\mathrm{Na}}$ or $G_{\mathrm{Ca}}$ varies depending on individual cells (see Fig. 12). Indeed, this seems to be the case, since there were large variations in the changes of the membrane conductance under the effects of ACh (Fig. 8). Furthermore, this is also substantiated by observations that effects of ionic changes in the perfusing solutions on the slow ACh potentials and depolarizations differed depending on

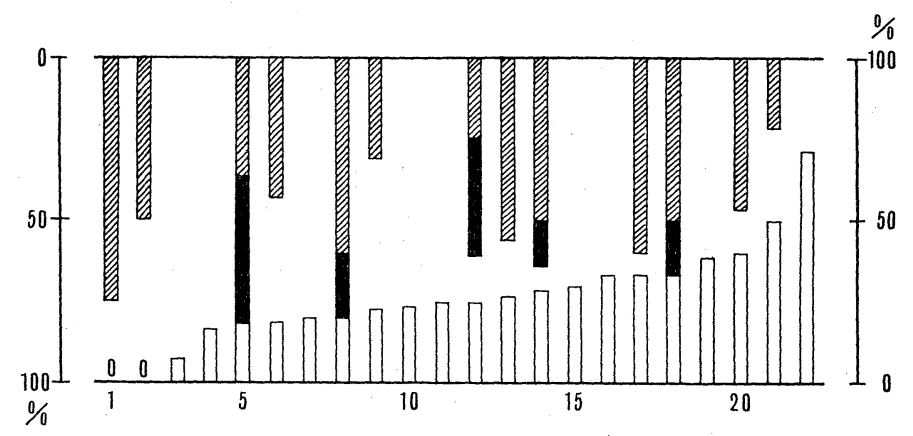

Fig. 13. Fractions of decreases in the amplitude of the slow ACh potentials or of the slow ACh depolarizations ascribed to effects of high $\mathrm{K}^{+}, \mathrm{Na}^{+}$-free (sucrose) and $\mathrm{Ca}^{2+}$-free solutions. White columns are the fraction of a decrease due to the high $\mathrm{K}^{+}$effect, and calculated by reducing the amplitude of the slow ACh potential or slow ACh depolarization in the high $\mathrm{K}^{+}$solution from that in the normal Ringer's solution. Shaded columns are the fraction of a decrease due to $\mathrm{Na}^{+}$-free (replaced with sucrose) effect, and calculated by reducing the amplitude of the slow ACh potential or slow ACh depolarization in a high $\mathrm{K}^{+}, \mathrm{Na}^{+}$-free solution from that in a high $\mathrm{K}^{+}$solution, or the amplitude in a high $\mathrm{K}^{+}, \mathrm{Ca}^{2+}$-free, $\mathrm{Na}^{+}$-free solution from that in a high $\mathrm{K}^{+}, \mathrm{Ca}^{2+}$-free solution. Black columns are the fraction of a decrease due to $\mathrm{Ca}^{2+}$-free effect, and calculated by reducing the amplitude of the slow ACh potential or slow ACh depolarization in the high $\mathrm{K}^{+}, \mathrm{Ca}^{2+}$ free solution from that in a high $\mathrm{K}^{+}$solution, or the amplitude in a high $\mathrm{K}^{+}, \mathrm{Na}^{+}$-free, $\mathrm{Ca}^{2+}$-free solution from that in a high $\mathrm{K}^{+}, \mathrm{Na}^{+}$-free solution. Data were obtained from 22 cells and arranged in abscissa in the order of magnitude of decreases in the ACh responses in the high $\mathrm{K}^{+}$solution. Ordinate on the left side corresponds to shaded columns, that on the right side to white ones and either of them to black ones. 
the cells examined. Percentages of decreases of these slow ACh responses caused by an increase in the $\mathrm{K}^{+}$concentration or by removal of $\mathrm{Na}^{+}$or $\mathrm{Ca}^{2+}$ are shown in Fig. 13. The decrease caused by an increase in the $\mathrm{K}^{+}$concentration ranged from $0 \%$ to $75 \%$, the decrease by removal of $\mathrm{Na}^{+}$were from $22 \%$ to $75 \%$, and the decrease by removal of $\mathrm{Ca}^{2+}$ from $14 \%$ to $46 \%$. These fractions of the decreases related to each ion would roughly indicate those of the $I_{\mathrm{K}}, I_{\mathrm{Na}}$, and $I_{\mathrm{Ca}}$ at resting potential levels.

Another interesting feature of the slow EPSP is the unusual non-linear relationships between its amplitude and membrane potential which were significantly seen in types 1 and 2 cells (Fig. 4). In these cells, the amplitudes of the slow EPSP and slow ACh depolarization became smaller when the membrane potential was made more negative up to a certain level, but further hyperpolarization resulted in a marked increase (type 1 cells) or no change (type 2 cells) in their amplitudes. This non-linearity can be explained by the voltage dependent nature of the overall changes in the membrane conductance under the effects of ACh seen in types 1 and 2 cells (see Figs. 5, 6, and 8). Unfortunately, there is no direct evidence to determine which components of membrane conductance $\left(G_{\mathrm{K}}, G_{\mathrm{Na}}\right.$, and $G_{\mathrm{Ca}}$ ) are responsible for voltage sensitivity of the overall membrane conductance. It may be possible that changes in the $G_{\mathrm{K}}$ by the action of $\mathrm{ACh}$ are potential dependent, if one assumes that the slow EPSP and the action potential of ganglion cells share the common ionic channels for $\mathrm{K}^{+}$. This assumption is based on the observations that there was a significant decrease in the amplitude of after-hyperpolarization of an action potential during the slow ACh depolarization even when the membrane potential was restored to the original level (KUBA and KoKETSU, 1975), and that there was a correlation between the magnitude of the decrease of the after-hyperpolarization and the amplitude of the slow ACh depolarization (KuBA and KoKeTsU, 1976). If this is the case, there is a possibility that the net decrease of the $G_{\mathrm{K}}$ caused by the effects of ACh would be much greater at membrane potential levels where delayed rectification is fully activated, since greater numbers of channels are available for closing at these levels. This would lead to non-linear relation of the $I_{\mathrm{K}}$ to different levels of membrane potential. This idea seems to be supported by the fact that the level, at which a change in the slope of the relationships between the amplitude of slow ACh depolarizations and membrane potential occurs, almost corresponds to that of threshold membrane potential for delayed rectification and by the findings that there is a shift of the threshold for the rectification in the presence of ACh (see Figs. 5, 6, and 7). The $I_{\mathrm{K}}$ shown in the schema of Fig. 12 was drawn based on these considerations and the assumption that the rates of inactivation of the $G_{K}$ were independent of membrane potential. Voltage sensitive changes in the membrane conductance by the muscarinic effects of ACh were also reported in the smooth muscle cells (BOLTON, 1974).

As shown in Fig. 10B, replacement of total $\mathrm{Na}^{+}$. with Tris did not affect the slow ACh depolarization. This may indicate that Tris ions are able to pass 
through the $\mathrm{Na}^{+}$channels responsible for the muscarinic response, unless one assumes the increases of the sensitivity of the postsynaptic membrane to ACh or its input resistance. Besides, the slow ACh depolarizations could be recorded in the high $\mathrm{K}^{+}$, isotonic- $\mathrm{Mg}^{2+}$ solution (Fig. 11B). These results would indicate that ionic conductance channels for $\mathrm{Na}^{+}$and $\mathrm{Ca}^{2+}$ may not be specific for these cations, but allow many other cations to pass. It is not known whether both $\mathrm{Na}^{+}$and $\mathrm{Ca}^{2+}$ pass through the same channels or each cations would pass through different individual channels.

This study was supported by grants $(137011,157044)$ from the Ministry of Education, Science and Culture of Japan.

\section{REFERENCES}

Blackman, J. G., Ginsborg, B. L., and Ray, C. (1963) Some changes in ionic concentration on the action potential of sympathetic ganglion cells in the frog. J. Physiol., 167: 374-388.

Bolton, T.B. (1974) Voltage-clamp experiments on the potential-dependent behaviour of membrane ion channels operated by the muscarinic receptor of smooth muscle. $B r . J$. Pharmacol., 51: 129P-130P.

Del Castillo, J. and Katz, B. (1955) Local activity at a depolarized nerve-muscle junction. J. Physiol., 128: 396-411.

Kobayashi, H. and Libet, B. (1968) Generation of slow postsynaptic potentials without increase in ionic conductance. Proc. Natl. Acad. Sci. U.S.A., 60: 1304-1311.

KoBAYASHI, H. and LIBET, B. (1970) Actions of noradrenaline and acetylcholine on sympathetic ganlion cells. J. Physiol., 208: 353-372.

KoBAYASHI, H. and LIBET, B. (1974) Is inactivation of potassium conductance involved in slow postsynaptic excitation of sympathetic ganglion cells? Effects of nicotine. Life Sci. (Oxford), 14: 1871-1883.

KoKetsu, K. (1969) Cholinergic synaptic potentials and the underlying ionic mechanisms. Fed. Proc., 28: 101-112.

KoKetsu, K., Nishi, S., and Soeda, H. (1968) Acetylcholine-potential of sympathetic ganglion cell membrane. Life Sci. (Oxford), 7: 741-749.

KubA, K. and KoKetsu, K. (1974) Ionic mechanism of the slow excitatory postsynaptic potential in bullfrog sympathetic ganglion cells. Brain Res., 81: 338-342.

KubA, K. and Koketsu, K. (1975) Direct control of action potentials by acetylcholine in bullfrog sympathetic ganglion cells. Brain Res., 89: 166-169.

KubA, K. and KoKetsu, K. (1976) The muscarinic effects of acetylcholine on the action potential of bullfrog sympathetic ganglion cells. Jap. J. Physiol., 26: 703-716.

LAmbert, D. H. and Parsons, R. L. (1970) Influence of polyvalent cations on the activation of muscle end-plate receptors. J. Gen. Physiol., 56: 309-321.

NisHi, S. and Koxetsu, K. (1960) Electrical properties and activities of single sympathetic neurons in frogs. J. Cell. Comp. Physiol., 55: 15-30.

NisHI, S. and Koketsu, K. (1968) Analysis of slow inhibitory postsynaptic potential of bullfrog sympathetic ganglion. J. Neurophysiol., 31: 717-728.

Nishi, S., SoedA, H., and Koketsu, K. (1965) Studies on sympathetic B and C neurons and patterns of preganglionic innervation. J. Cell. Comp. Physiol., 66: 19-32.

Nishi, S., SoedA, H., and Koketsu, K. (1969) Unusual nature of ganglionic slow EPSP studied by a voltage-clamp method. Life Sci. (Oxford), 8: 33-42.

Tosaka, T., CHichibu, S., and Libet, B. (1968) Intracellular analysis of slow inhibitory and 
excitatory postsynaptic potentials in sympathetic ganglia of the frog. J. Neurophysiol., 31 : 396-409.

Weight, F. F. and VotaVA, J. (1970) Slow synaptic excitation in sympathetic ganglion cells: evidence for synaptic inactivation of potassium conductance. Science, 170: 755-758. 